\title{
The Abolition of Man ${ }^{1}$
}

\author{
lan Hacking
}

\begin{abstract}
Scepticism and fear about biotechnology is widespread. It takes two important literary forms, namely dystopias and jeremiads. Neither is compelling in itself, but together they provide a strong collection of arguments for great caution. The dystopias examined here range from Aldous Huxley's Brave New World to o two recent novels by Margaret Atwood. The Jeremiads range from C. S. Lewis in 1942 to Habermas and Fukuyama.
\end{abstract}

Keywords: biotechnology; Habermas; C. S. Lewis; Margaret Atwood; Fukuyama

My topic is a pair of profound fears in the face of biotechnology. One is the material fear, that by changing the physical or mental constitution of our descendants we may do irreparable harm to ourselves as a species. Another is the apprehension that it is morally wrong to mess much with the genome of individuals, or, more universally, with what is called "the human genome".

My title refers to the title of a set of lectures given in the middle of World War II by the English man of letters and Christian apologist, C. S. Lewis (Lewis 1944). The third of these was curiously prescient, anticipating, in some ways, recent concerns of Jürgen Habermas. He was worried that bad things were in store for the human race. New sciences and technology might somehow erode or destroy traditional human values. They might also alter the human race that it would no longer be human, or humane, or humanizing. So we should be resolutely wary of any biotechnology trying to make fundamental changes in the human constitution. Such activity is, of course, far more viable in 2010 than in 1942.

The two fears just mentioned lead to a species of bio-conservativism. It is conservative in the best sense of the word, reminiscent of Karl Popper, Friedrich von Hayek, or Michael Oakeshott: preserve what is valued and has served us quite well; be very cautious about radical changes whose consequences cannot be predicted with confidence. There are many other bio-conservative movements afoot. Opposition to genetically modified foods, fear of cloning and doubts about stem cell research happen to be most often in the press nowadays. One can be conservative about the breeding of some creatures by oldfashioned know-how. I myself have voiced outrage at the fact that virtually all North

1 Lecture in the series Wissen und Ordnung commemorating the $600^{\text {th }}$ anniversary of the University of Leipzig, $9^{\text {th }}$ August 2009 and The Owen G. Holmes lecture, University of Lethbridge, $16^{\text {th }}$ September 2009 
American turkeys must be bred by artificial insemination, a consequence of the fact that the Tom is so heavy that he would crush the hen to death if he were to mount her. (Hacking 2008 , 147) One could be a bio-conservative about transplanting body parts from the recently dead to the ill among us. In fact in the West, but not in Japan, the practice was so quickly accepted that we redefined death, a truly amazing un-conservative act, in every sense you might attach to that made-up expression (Lock 2002). My interest here is a specific bio-conservative attitude that strongly resists interfering with the human genome, or even the genome of individual human beings.

One example is Habermas' essay Zukunft der menschlichen Natur (Habermas 2001). A second example was published the next year: Our Posthuman Future: Consequences of the Biotechnology Revolution (Fukuyama 2002). Francis Fukuyama is famous for his thesis about the end of history. He believes in the inevitable triumph of the free market, suitably regulated. Habermas is one of the most articulate opponents of Fukuyama's type of political philosophy. But both are fearful of biotechnology, and its corollary, a new kind of eugenics. Like the prophet Jeremiah, they are prophesying damage or disaster to mankind, if we do not take care to mend our ways.

Hence I chose for the title of this lecture one of the older jeremiads, C. S. Lewis's $A b$ olition of Man. He had a vision of human beings ruined by scientific and technological modifications of, as we would now say, our genome. But he also had deeply moral considerations. Future humans may have their condition, their very nature, pre-arranged by previous humans without having any say in the matter. The "Conditioners", as Lewis calls them - the well-intentioned scientists - will have selected what types of human beings will exist in the future. Perhaps what they select will not be human, as we understand ourselves, at all. And this is to defraud future humans of their birthright to be "truly" human. $^{2}$

\section{Jeremiads and dystopias}

In Hebrew, Christian and Muslim tradition, the prophet Jeremiah is associated with two biblical books, The Book of Jeremiah and the Lamentations. There is some agreement that the Lamentations are by another hand, while the dire prophecies Jer. 1-25 are his, transcribed by his secretary Baruch. ${ }^{3}$ He inveighed against the sins of his people, and foretold catastrophe if they did not mend their ways. A jérémiade, a fairly recent noun perhaps introduced by Voltaire, has a pretty negative connotation in French, importune nagging. ${ }^{4}$ English is less judgemental: the $O E D$ defines a jeremiad as a complaining tirade. A recent Webster's Third International all too casually defines it as an angry harangue. The German Jeremiade seems to be closer to the Lamentations than to the cruel

2 "In the Tao itself, as long as we remain within it, we find the concrete reality in which to participate is to be truly human: the real common will and common reason of humanity, alive, and growing like a tree, and branching out, as the situation varies, into ever new beauties and dignities of application." (Lewis 2001, 74-75, my italics.) The Tao is Lewis's name for a set of human values widely diffused throughout the planet; see below.

3 His secretary Baruch is probably the author of the biographical material in chs. 26-45. Chs. 46-51 are oracles against foreign powers, while ch. 52 is a standard historical summary of the fall of Jerusalem.

4 The Trésor de la langue française gives "plainte, lamentation, récrimination sans fin et importune". 
prophecies of the Book of Jeremiah. For all the ambiguity, I think that the grim warnings of Jer. 1-25 allow one to call the books by Habermas and Fukuyama jeremiads.

Utopia was the name of Thomas More's imaginary island (More 1516, 1517) with the best possible social arrangements. Speaking to Parliament in 1868, John Stuart Mill coined the word "dystopia" for a worst possible state of society. I shall notice below that Jeremiah himself prophesied some pretty grim dystopias. We now call stories of ideals utopian, and tales of horrors dystopian. Dystopias imagine a worst possible world in order to confront directions in which we may be heading. The difference between a jeremiad and a dystopia is more of genre than of intent.

Scepticism about eugenics, or in general genetic engineering of people, has produced its share of jeremiads and dystopias. I shall notice some notable ones, arranged by dates: 1932, 1942, 1997, 2001, 2002, and 2003.

\section{Dystopias and jeremiads need each other}

The most calamitous warnings of jeremiads are founded on argument, although Jeremiah himself could also rely on what the Lord told him. Our jeremiads argue that scientific intervention in the human genome is dangerous, both in terms of the material changes that may result, and also in terms of our moral responsibility for children yet unborn. This is despite the fact that at present we have every reason to believe that the biotechnologists have the best intentions, and despite their much-praised prospects for improving the human condition. ${ }^{5}$

The arguments of the jeremiads are (in my opinion) weak, and the visions of the dystopias are not probable. Neither can stand alone. I shall maintain that together they form a powerful rhetorical alliance. This is especially so when my chosen dystopias were written some seventy years apart, and when my chosen modern jeremiads are argued from opposed ends of the political spectrum. Although a "precautionary principle" is implied, the dystopias have a greater force because they suggest a literally inconceivable chain of events, which, by definition, the authors cannot conceive, but which remains in the realm of the hinted-at possible. They drive along the jeremiads, which, being arguments, cannot reach as far as the dystopias. Yet the jeremiads interpret the dystopias with a solemn rendering of conclusions.

In the context of biotechnology, each of the two genres examines, in its own way, the selection of future human beings, in a strictly biological sense of the word "selection". Before we rush into the moral fray, we should recall a few facts about the very idea of selection, which takes us back to the Origin, that is, to Darwin.

\section{Human selection of natural variation among humans}

Darwin had three types of selection. His first chapter in the Origin was about selection of individuals from variation in domestication: breeding cattle or varieties of tomato. This is not always in the interest of the varieties selected: recall the shameful way in which we have bred turkeys for our consumption by destroying their nature. It is of course in the

5 The optimistic version that is implicitly challenged by the jeremiads is elegantly stated by the eminent and immensely imaginative senior physicist, Freeman Dyson (Dyson 2007). 
best interest of turkey genes: there are innumerably more of them strutting around than there were fifty years ago, let alone at the time of the first American Thanksgiving.

Selection from variation led Darwin on to natural selection. That was his great innovation, although we casually speak of him as "discovering evolution," which he did not. Then there was sexual selection. Darwin speculated that this had a lot to do with the stabilization of racial phenotypes. He started with peacocks; if the sturdiest peahens mate with peacocks with the fanciest tail feathers, then over generations fancy tail feathers will be favoured, and the race will become fancier and fancier. Likewise, to use a foolish example to suggest the reasoning, if the males of the Campbell clan, for example, favour and compete for a certain type of bonnie Scottish lass, the lasses will become, over the generations, more and more different from the Celtic girls of Brittany, where the males have a different canon of beauty. That assumes a sort of reinforcement of choices, which may be far more cultural than biological.

All mating is a selection of genes for offspring, but the selection is seldom a conscious one. Rare is the person, even today, who deliberately chooses the mate in order to have children with desirable characteristics. Evolutionary psychologists teach, moreover, that our sexual choices are largely pre-programmed. If that were so, our tastes in mating would already have been settled by natural selection. If the psychologists were right, the selection of the genes for the progeny of a union would not only be unconscious but also pre-programmed.

That does not leave much room for human selection from natural variation among humans. There is some. Advancing soldiers rape. This ensures that the conquered women produce children with the genes of the victors, not those of the defeated. Is that always unconscious selection? Some have suggested that Stalin and his advisors had eugenic intentions for the Soviet conquest of the Eastern part of Germany. Others contend that Franco in Spain got there before Stalin, ordering his troops systematically to rape women in Republican areas in order to upgrade the Spanish population (as if being a socialist were a heritable trait). The appalling scenes in the Congo right now may have similar effects, and even similar motivations, even if they are less well articulated than those attributed to Stalin.

Once Darwin had drawn lessons from selection of naturally occurring variants, his contemporaries began to think about selecting human beings. His ingenious cousin, Francis Galton, coined the noun "eugenics" in 1883 (Galton 1883, 44). He meant the "condition under which men of high type are produced." It soon came to mean the study of ways in which the human race could be improved to yield "men of higher type." Then eugenics became the name of an influential political programme in late Victorian England.

\section{Old eugenics}

The British middle classes worried that labourers were breeding too fast, reproducing undesirable traits. Eugenics transferred to America as a theoretical excuse for excluding the least likeable races of Europe. (Asians were not on the cards.) Swiss and Swedes alike embraced it for their own purposes. Alberta, a province in Western Canada, had a Sexual Sterilization Act in force from 1928 to 1972. It was intended to eliminate the mentally handicapped. It targeted native peoples, Métis, and Albertans of Ukrainian ancestry. The Nazis married eugenics to murder, while furnishing excellent child support to large "Aryan" families. Now no one dares to speak the name of eugenics in a favourable tone of voice. 
The original English eugenics relied on tax incentives and educational reform. The poor would be rewarded for having few children; the middle classes for having many. Intelligence tests inspired by Galton would be used to select poor but brainy children for education after eleven, and hence prepare them for induction into the talented middle classes. That was the origin of the "eleven-plus" system in effect in England, 1944-1972.

Galton had proved that able people had less able children. He called it regression to mediocrity; we now politely call it regression towards the mean, a primary tool of statistical inference. Hence there should be drastic inheritance taxes, to prevent mediocre children of gifted parents from reaping unearned and undeserved benefits. The emancipation of middle-class women would be useful, for they were the good breeders. Many male eugenicists supported the suffragettes. Any resemblance to Fabian socialism is purely non-coincidental. Had I been there a century ago, in 1910, I should probably have been a eugenicist. The abuses to which the eugenics programme was turned long before it reached the Nazis (think Sweden or Alberta) are an object lesson to all high-minded planners who contemplate tilting the evolutionary playing field.

Notice, however, that we already practice some types of individual eugenics. Mothers can determine that their fetus is likely to have Down's syndrome, and choose to abort. The man who in 1958 discovered the cause of the syndrome, Frédéric Lejeune, was horrified that the presence of trisomie, a third chromosome 22, had become, as he put it, a symptom of death, namely abortion. Unlike Lejeune, I fully support mothers who abort Down's syndrome children, but let us not fool ourselves. That is a eugenic choice, but it is an individual one, which is characteristic of the new eugenics, not the old.

\section{New eugenics}

The old genetics began as paternalism, became authoritarian, and morphed into dictatorial brutality. It decided which classes of people should breed, and which should not. That is no surprise: it was devised by statisticians and socialists. (Please don't infer from my words that my politics lie on the right; I too am a secular socialist, and something of a statistician.) Future eugenics will be different: it may be almost libertarian. Rich people in a market economy will choose which innovations, patented by biotechnology companies, to incorporate into their personal breeding plans.

Therapy and enhancement are usually distinguished here. Genetic therapy aims at altering or eliminating genetic material connected with life-hindering traits. Enhancement aims at upgrading heritable material. Enhanced children will be stronger, more intelligent, live longer, run faster, or whatever their parents want.

After a moment's thought the distinction blurs. For example, my great-grandchildren may eliminate the myopia I inherited from my father and which they inherited from me. That would be genetic therapy. (You may say, Hacking can't be myopic, for he seems to be reading from a text without spectacles. You are fooled: I became legally blind and now see with implanted plastic corneas, a tidy bit of biotechnology for which I am so grateful.)

Now consider the fact that human visual acuity peaks at about age 13. Many children of that age can distinguish the four planets of Jupiter in a clear night sky. Almost all of them have lost that ability a few years later. And of course adults become far-sighted after the age of 40 or so. But now imagine that the loss of visual acuity soon after puberty is genetically engineered away; and the same with age-related far-sightedness. Such changes will be, relative to our current condition, enhancement. But what is the difference 
between this and the therapy I imagine for my myopic progeny, which I called therapeutic?

In mentioning these imaginary cases, always have the salt shaker to hand. There is not the slightest reason to think that such genetic emendation is practicable in any plausible near future. Conversely, never shut the door on possibility. My corneal surgery was fantasy two decades ago.

\section{2}

Aldous Huxley published Brave New World. An English speaker knows, from the title, that the New World imagined by Huxley is going to be advertised as a blissfully happy one, but that in fact is a lie; it is a horrible place. "Brave" has to be ironic. In Italian the book was published as $\mathrm{Il}$ mondo nuovo, which is not ironic at first hearing. German does a bit better with Schöne neue Welt. French can do it, thanks to Leibniz and Voltaire, for the translation is Le Meilleur des mondes.

Aldous Huxley, born into a family of leading British scientist-intellectuals, knew what was going to happen in the sciences of human life long before other writers of science fiction; he also grew up in the social ambience of supporters of eugenics. In only two respects was he notably wrong: First, the date, 2540 (632 AF, that is, 632 years after Ford, or Freud). Second the setting, the "Hatchery and Conditioning Centre," in Central London, where human beings are custom-made from the contents of test-tubes, and then moulded to fit their various social castes. The place and dates are wrong: If Huxley's prophecy is fulfilled, it will be much sooner and somewhere else. London was the centre of the universe, at least for Huxley writing in 1932, but now it is just another interesting old European city, no different from Rome or Paris or Berlin. If I were to re-set the novel, it would be in 2040 at latest, that is, 30 years from now, only a century after Huxley published, and the setting would be Shanghai, which by then will be the biotechnology capital of the Universe.

The other great dystopia of an earlier time is George Orwell's Nineteen Eighty-Four (which was published in 1947, when the next year would be 1948; in English, forty-eight is eighty-four backwards). Aldous Huxley briefly taught George Orwell at Eton. Nineteen Eighty-Four is the great dystopia of information control, parallel to Huxley's horror story of human design of posthumans. Both novels are built around a survivor or two, still striving for human dignity. They want to claim their human identities. In Huxley's case, they try to repel the eugenicized wasteland.

1984 was a real threat in 1948, so recently post-Hitlerian, with Stalin in charge of a lot of Earth's landmass. So far as we can tell from present-day technology, there is no longer any immediate danger of anything remotely like 1984. The Internet is an amazing liberator of information. It seems impossible to control it. An ecoterrorist could drop a few well placed bombs, including several large ones on the Googleplex, Google headquarters in Mountain View, California. That would knock the stuffing out of the Internet, but it would require a dictatorship of demonic skills to create a new group of controlled search engines which could not be overcome by hackers. The Internet is, for any foreseeable future, an implacable force of democratization, nay, anarchy. Perhaps it is a parody of John Stuart Mill's liberal confidence that the truth will win in the end, for we may all drown in a sea of random misinformation. But for the time being, dictatorial control of information as in 1984 is obsolete, while Huxley remains prescient. 
In one central respect, however, Brave New World is out of date, because the system was paternalistic. In that novel, scientists have created their vision of super humans, and also engineered slaves. There are various classes in between, labelled by letters of the Greek alphabet, just as pupils in elite English schools were, and indeed in some cases still are, graded as alpha and so on down. One hero of the book, Bernard, is an alpha-plus, the top grade still current in Oxford. The aim of the scientists was to improve the race. The motto was "Community, Identity, Stability." Both Orwell and Huxley were writing about well-meaning socialism gone mad, with aims and results different from the historical projects of National Socialism, but in some ways worse. The new eugenics, so far as we can anticipate it, will be of an individualistic stripe, free market rather than socialist.

\section{2}

Nowadays C. S. Lewis is most remembered for his fantasy, The Chronicles of Narnia: The Lion, the Witch and the Wardrobe. It has sold 100 million copies in 41 different languages. I read it to my children. It was supposed to be morally uplifting, and indeed a Christian parable, but my kids never seemed to get the background message. They just loved the tale. Tolkien and Lewis were two of a kind, old-fashioned Oxbridge colleagues in the study of early English, and weavers of high fantasy that caught the imagination of the world.

Lewis was steeped in the classics of Western civilization and deeply respectful of other cultures; he was also a convert to a serious English Christianity, a devout middle-ofthe-road Anglican. In the midst of WWII, 1942, he gave three lectures under the eccentric title, The Abolition of Man, or, Reflections on Education with Special Reference to the Teaching of English in the Upper Forms of Schools. They began with a devastating critique of some manuals for teaching English to the future elite of England (in the senior forms, which in those days most English children never reached). He is quite funny, if you have a taste for nineteen-forties Oxbridge wit. He proceeds to a spirited defence of central values shared, he says, by all peoples. The book ends with an appendix of 120 sayings from around the world - from the usual suspects, the great civilizations or religions, but also from Norse texts, Australian aboriginals, and the Dakotas. These, he says, express The Way, the Tao of all humanity. (Remember this is 1942, long before New Age babblers devalorized the Tao.)

Only four of the 120 aphorisms are specifically Christian, but the book is commonly taken as a defence of Christian morality. It is not. Lewis argues that to abandon the universal values represented by his 120 sayings would be to abandon our common humanity. In that metaphorical sense we would be "abolishing man". But only in the third lecture do we get to the literal abolition of man through biotechnological advance.

The practice of eugenics and losing touch with the Tao will, he claimed, diminish or destroy the worth of human beings. "For the power of Man to make himself what he pleases means [...] the power of some men to make other men [men yet unborn] what they [the makers] please." (Lewis 2001 [1944], 86) Don't say that we, the human race, will be in charge of our own biological destiny. It is the Conditioners who will de facto be in charge, even if they are regulated by other high-minded persons.

Unlike educators who have tried to mould the young, "the man-moulders of the new age will be armed with the power of an omnicompetent state and an irresistible scientific technique: we shall get at last a race of Conditioners who really can cut out all posterity in what shape they please" (Lewis 2001 [1944], 59-60). Notice how his pessimistic realism 
pays attention to the fact that over some generations the Conditioners too will become a new "race," or at least part of one, literally Masters of creation. ${ }^{6}$

Two features of his jeremiad are memorable. First, Lewis understands, at least some of the time, that a chief danger is not paternalistic eugenics but individualistic free market eugenics. Thus, almost unwittingly, he has shifted the terrain. I mentioned aborting Down's syndrome children, which of course was impossible before 1958 when trisomie was identified as the cause. But free market eugenics kicked in earlier than that, as Lewis observes: with contraception. This is negative eugenics, merely determining that a lot of couplings will have no issue, although it can also be positive, as when a couple carrying the potential for manifestly defective children decide not to procreate. In a very limited way we are deciding on the future genetic make-up of the next generation: our kind will not be represented. There is no future person whose liberties and rights we are infringing. Yet Lewis uses contraception as a stepping stone to biological therapy and finally biological enhancement, not because he maintains that contraception is intrinsically wrong, but because it awakens a desire to determine which children shall be born.

He argues that choices made by one generation, about the genetic make-up of future generations, diminish the freedom of later generations. Future beings did not choose what to be - or in the case of contraception (and its successors in person-elimination) not be. Hence the choices made now for the future are an assault on human dignity itself. We shall find the idea developed by Jürgen Habermas. But don't we do the same when we choose systems of education for the young? Yes, but the effects are short-term. Theories on how to teach are fads that pass. "Locke wants children to have leaky shoes and no turn for poetry." No kidding: Lewis cites Locke's Some Thoughts Concerning Education, §7, $\S 174$ (Lewis 2001 [1944], 60). Happily, good sense undoes educational reformers. "We may well thank real mothers, real nurses, and (above all) real children for preserving the human race in such sanity as it still possesses." The trouble with genetic alteration a few generations down the line is that it cannot readily be cancelled by the next fad, and what we now call the common sense of mothers may be diluted or itself altered.

Lewis backtracks from an emphasis on individual choice and returns to the paternalism of the Conditioners, those select few who decide for the future. He drops the theme of genetic choices in a free market. He does develop a thought about the sciences that matured in Carolyn Merchant's book, The Death of Nature, a work of the first wave of recent feminism. (Merchant 1980) Science as born in the sixteenth century begins to treat nature as an object. We bend Mother Nature to our will, says the prophet, Francis Bacon. Bacon "condemns those who value knowledge as an end in itself; this, for him, is to use as a mistress for pleasure what ought to be a spouse for fruit." ${ }^{8}$ (Lewis 2001 [1944], 78)

6 This is not dystopia but jeremiad, although the vision of an untrammelled genetic future is surely dystopian. Lewis also wrote a trilogy of dystopian novels, incredibly inferior to Huxley, I have found that even the most devoted of Lewis's admirers have seldom looked very far into Space Trilogy, published 19381945. These books, Out of the Silent Planet (1938), Perelandra (1943), and That Hideous Strength (1945) are astonishingly bad science fiction unworthy of the inventor of Narnia. Unlike the Narnia Chronicles, their Christian implications are, to put a brave face on it, sickly, or, to be unkind, sickening.

7 See the September 2006 issue of $I S I S$ for a $25^{\text {th }}$ anniversary retrospective discussion of this work, including Merchant's own defence of her use of Francis Bacon.

8 Merchant rather famously emphasized Bacon's sexist language. Notice that C. S. Lewis did so four decades earlier. 
First we treat nature as an object. Then we treat human nature itself as an It that we can alter. In so doing the Conditioners lose their way. By objectifying humanity they distance themselves from the Tao in which humans as subjects participated.

It is true that the Conditioners make choices about the future constitution of unborn children, but why is this intrinsically wrong? We may be pessimists, and expect them to be technocrats that care little for human values, but that is at most a prejudice of some humanists, not an argument. Perhaps the prejudice can be defended with Lewis's reflection on the evolution of the Conditioners themselves: as a by-product of their activity, traditional values may lose their hold. In my opinion, the argument at this juncture is not coherent, but the idea is potent; the rhetoric of the final pages sounds good to many people. Lewis even ends with a fantasy of a science different from ours, humane; he mentions Goethe as a possible model, but does not develop the idea. ${ }^{9}$

\section{7}

Half a century after C. S. Lewis, sixty years after Aldous Huxley, the world was awash with both science fiction and biotechnology. There were endless horror stories in movies and on TV with biotechnological themes. The appendix to a recent study of biotechnology and the media provides a staggering list, with a focus on cloning, but covering a lot of the waterfront..$^{10}$ (Haran et al. 2008)

Gattaca (1997) has a wide following and will serve as exemplar. The very name is built of elements of the DNA code, G, A, T, C. In the near future, genetic engineering is commonplace, but not quite up to the standards of Brave New World. Social class is determined by DNA. An instant genome-reader distinguishes between alphas and those below, in particular, between the valid and in the invalid (in-valid) individuals. In-valids perform all the menial tasks. An in-valid named Vincent tries to pass for valid in order to become an astronaut. He is a janitor in the plant of a space corporation but uses drops of blood, urine etc. from a disabled alpha-plus (who is an invalid in the usual sense), in order to get past the genome readers and on to the stars. The stunt barely succeeds.

Although the film is widely viewed as powerful social criticism of a future biotechnological planet, but in fact the film is singularly lacking in social criticism. The hero is the lone individualist, the twenty-first century equivalent of the all-American heroes in the novels of Horatio Alger Jr. (1832-1899). Physically and mentally he is well qualified, but his genes still count against him, so by sheer pluck and ingenuity he overcomes all the disadvantages of his pre-assigned social status. We do not like the bad guys who help run the system, but the system is how it is. There are no moral issues at all.

Code 46 (2003) has, mutatis mutandis, the same plot as Gattaca: this time it is starcrossed lovers in a world where couples may procreate only if their genes match up in desirable ways. But let us take the OED definition of a dystopia: "An imaginary place or condition in which everything is as bad as possible." I am not sure that any of the 80-odd

9 One way to develop it is to pursue Pierre Hadot's (2006) distinction between Promethean and Orphic science. Goethe (foe of Newton on the colours and much else) was always Hadot's exemplar of the Orphic.

10 The authors are British, but most of the films are American with a sprinkling of Japanese. A cloned, resurrected (or something) Josef Mengele figures as the arch-villain in two of the four German films cited. The television list consists mostly of British products. See also Stacie (2009). 
films in the list mentioned in note 16 count as biotechnological dystopias, in the strict sense of that word. Things are really bad for Vincent, or for the lovers in Code 46, but the worlds in which they find themselves are pretty good unless you're unlucky, and are discriminated against because you have done poorly in the birthright lottery. ${ }^{11}$ How like the USA and the race question. (Vincent, I said, tried to pass as valid, just as some blacks for generations have tried, and sometimes succeeded, to pass as white.)

In contrast, consider how Huxley's brave new world, or the world of 1984, fills every reader with revulsion. We are moved not by pity for the hero, for whom one must root in the spirit of Horatio Alger, but disgust at the world imagined. Fictions offered social criticism in the good old days, but in our century we may have to turn to intellectuals. Or at any rate, intellectual novelists.

\section{1}

Jürgen Habermas published several lectures, Zukunft der menschlichen Natur: Auf dem Weg zu einer liberalen Eugenik? I shall refer to it by its English translation, which appeared without the subtitle in 2003: On the Future of Human Nature. "Liberal" in Europe means free-market, laissez-faire capitalism, and so liberal genetics means freemarket genetics, among other things. The American sense of the word "liberal" is almost the opposite of the European one, and so confusion results. On the other hand, I think my label "bio-conservative" is self-explanatory in this context. Habermas recently wrote me (26 August 2009): "I never thought that any version of 'conservatism' would apply to me, but 'bioconservatism' is a wonderful term!"

Habermas is the magisterial German philosopher who since WWII has systematically addressed the fundamental moral and social issues of Germany, Europe and humanity. He understands, much better than C. S. Lewis did, that the great peril of the future is not paternalistic but "liberal" eugenics. Lecturing some sixty years after Lewis, he is familiar with biotechnology present and proposed, and also with political controls that have been or may be imposed on it, especially in Germany. He makes a strong distinction in principle (but acknowledges the blur in practice) between therapeutic eugenics and enhancement eugenics.

I have already been sceptical of the distinction, but real-life examples may illustrate the complexities. Here is one of a very "ordinary" sort, which had probably not occurred to anyone ten years ago when Habermas was writing. Children and adolescents get cancers. They are regularly treated with radiation, which terminates their reproductive abilities. But eggs of girls (and sperm of boys) can be extracted and frozen for later use. In the case of girls, the viability of the frozen eggs is many times greater if the egg is fertilized. Thus one way to increase the probability that a child's egg can later grow into a fetus in her own womb is to fertilize it. With whose sperm? Talk about making a decision for children yet unborn. Are we providing therapy for the girl, or enhancement? This is not a question of future technology but of the present: such ordinary questions will multiply merely as present-day technologies become refined. ${ }^{12}$

11 I have taken the phrase from Ayelet Shachar (Shachar 2009).

12 For girls there is sometimes another option: the ovary can be replanted somewhere else on her body that is not cancerous, her arm, say. More incredible biotechnology! Frozen boy's sperm presents another, to 
Habermas would allow genetic therapy for an individual with Huntington's disease. It is one of the very rare genetic ailments whose locus is a single point on a single chromosome, namely on the short arm of chromosome 4 . Would he allow genetic intervention which prevented, in all human beings, the extremely complicated process that leads to an aberration in this locus which produces certain bad proteins which mess up certain neurons? From a moral point of view, could we decide that no future generation has the disease? That is deciding for the future too, but presumably he would allow it, on the ground that no sane person in the future would want to develop Huntington's disease as they approach middle age.

One of the things that Habermas fears is genetic shopping by parents able to do so. Consider the excesses by which prosperous Americans spend a fortune on their children to increase their chance of getting into Stanford; rich Indians do the same to get their infants into the best primary schools in Delhi. Suppose that instead of going into debt to get their kids into the right school, they can pay geneticists to ensure better brains or better bodies for their children. Habermas does not think that the parents have the right to make such choices. (We could see the geneticists who take the job as akin to the physicists who made atomic weapons, but not, I think, as Mengeles.) This kind of worry may simply be the fruit of too much imagination. Steven Rose, a distinguished neurologist who is also a first class popularizer, thinks we have greater reason to worry about the present, the advantage that the middle and upper classes have in respect of education, than any future brain steroid or genetic alteration (Rose 2005).

To return to the philosophical point, Habermas shares C. S. Lewis's fear that decisions made in one generation, to enhance the human race, are necessarily made without consulting the people who are born later, and so detracts from their dignity, their autonomy, their personhood, and their identity itself. They become objects that we, the present generation, designed, not subjects that form their lives. These reflections are especially pressing in the context of Habermas' moral and social philosophy, in which communicative deliberation among involved parties serves as the foundation of civil society. Habermas founds his argument on his political philosophy, which, from a logical point of view is a step up from Lewis's pessimistic fear about the Conditioners.

Habermas is concerned with the near future, although he is also fearful about later times if we become permissive now. But I unexpectedly find in C. S. Lewis a more powerful bio-conservative rhetoric - I dare not say argument. This is because he couples the power to change our descendants with a loss of moral sensitivity to the point that human nature itself is abolished.

Habermas's title was, you recall, The Future of Human Nature. Lewis did not, I think, use the expression "human nature." Instead he wrote of "Man," our species, in a way that is no longer politically correct. But he did offer a sketch of what dignifies us as human beings, namely those 120 sayings from all the corners of the earth, and which constitute what he calls the Tao. As rhetoric, that may move us, but as argument, it is feeble. I know of no present evidence that scientists who tinker with genomes, including the human one, have as a rule less moral sensitivity than other persons of the same social status and level

my mind less pressing, ethical question. Suppose his sperm is frozen; do his parents own his sperm and can they use it to produce their own grandchildren? I thank Jennifer Flynn for posing these questions to me. 
of education. But there remains his nagging fear, which does not appear in Habermas' more controlled deliberations, that future Conditioners will lose their moral way.

\section{2}

Francis Fukuyama published Our Posthuman Future: Consequences of the Biotechnology Revolution. He is the geopolitical expert who became famous for his essay, "The End of History." It was published in 1989, and continued as a book in 1992. He argued that Hegel was right: History ended in 1806 with the triumph of Napoleon at the battle of Jena, therefore cementing the Enlightenment ideology of the French Revolution. The twentieth century tried to remake history by trying out communism, socialism, fascism, and National Socialism; their collapse is the fulfilment of what Hegel understood. In 1989 the Berlin wall crumbled, with Hegel dancing on the rubble (or so we imagine Fukuyama saying).

In Posthuman Future Fukuyama writes that "One important reason for this worldwide convergence on liberal democracy [after the collapse of 'the socialist revolutions in Russia, China, Cuba, Cambodia, and elsewhere'] had to do with the tenacity of human nature." (p. 14). But the worldwide hegemony of "liberal democracy" (whatever that means) is not, he came to realize, the end of history. History will not end unless science and technology stop finding out new things to do and how to do them.

"The aim of this book is to argue that Huxley was right; that the most significant threat posed by contemporary biotechnology is the possibility that it will alter human nature and thereby move us into a "posthuman" phase of history. This is important, I will argue, because human nature exists, is a meaningful concept, and has provided stable continuity to our experience as a species." (Fukuyama 2002, 7)

Habermas put "Human Nature" into his title, but Fukuyama uses this phrase in itself as the basis of his entire argument. "Any meaningful definition of rights must be based on substantive judgments about human nature." C. S. Lewis gave us 120 memorable sayings from around the world to illustrate what he thought was the core of human values, the Tao. Habermas philosophy as provided an implicit model for the human nature of his title, namely communicative rationality. But Fukuyama does not do us the same favour; moreover, his "human nature" seldom considers non-Western human beings except when they adopt Western political systems.

Of course we use the phrase "human nature" happily enough: "that's just human nature." But what does it mean to say that human nature exists? Presumably, that there is some fundamental essence, Human, of which all human beings partake. Fukuyama claims that Socrates and Plato put the discourse of human nature into circulation, and that it kept right on through the Western tradition, presumably up to the Battle of Jena, 1806, and Hegel's End of History. Fukuyama does notice that "the concept [of Human Nature] has been out of favor for the past century or two with academics and intellectuals." (Fukuyama 2002,13)

There is a slightly different story to tell. Human Nature, so named, is a concept of the Enlightenment, of eighteenth century European high civilization. It was the moral and social essence of cultivated Europeans, something to be discussed in the great salons run by the amazing women of Paris. The French Revolution, The American Revolution, and the often ignored Haitian Revolution of 1791 made Human Nature essential to their ideologies. We inherit those ideologies. They inspired those great new values, equality and freedom, and the idea of Human Rights. This story completely tallies with Fukuyama's, 
except that it makes plain that the notion of Human Nature emerged in a historical situation (one of enormous value to Western civilization), rather than simply referring to a timeless essence that just "exists."

Fukuyama was right about one thing: the idea of Human Nature has been out of fashion "for the past century or two." More precisely, for the 150 years preceding the publication of E. O. Wilson's manifesto of sociobiology, On Human Nature (1979). 150 years exactly? Yes. Its previous big fling was in 1829. James Mill, father of John Stuart Mill, had written a utilitarian tract On Government. A young man, none other that Thomas Babington Macaulay, savaged it with cruel irony:

"Certain propensities of Human Nature are assumed; and from these premises the whole science of Politics is synthetically deduced.","

The complaint is compelling. An entire edifice is erected on a few unexplained assumptions. Replace "Politics" by "Geopolitics" and you can level this complaint at Fukuyama too. But the situation is worse, because Fukuyama equivocates on a grand scale. He takes the Enlightenment vision of Human Nature, which he rightly says help forge Western ideals, and equates it with some timeless "Human Nature" which seems to be the essence of our species. Not a growing tree of human values, as in Lewis, but an essence, cold and immutable so long a biotechnology does not interfere.

Fukuyama invokes Huxley, but does not seem to notice the difference between the paternalistic or authoritarian eugenics that was Huxley's target, and the free market individualistic eugenics which he himself takes for granted as the natural upshot of human nature and the end of history. His book is an argument for regulating the market in eugenic technology, for fear that "human nature" itself will be altered.

Some fear that regulation is hopeless. Fukuyama does have a counter here. He observes that although in theory we have made a terrible hash of nuclear weapons, in fact we have muddled through rather well, with agreements and conventions that gradually diminish some risks. No one has been killed by a nuclear weapon since 1945 . Every year the threat changes; once it was the exchange of ICBMs; now it is more likely to be stolen materiel put to destructive purposes. Nevertheless, the genie has been kept in the bottle. Regulation has not been futile.

\section{A modest bio-conservative upshot}

Habermas is committed to the values of a social democratic pluralistic society. It is the world in which he, as a German citizen, as a European, as a Westerner, and as a human being, is actually living. Fukuyama believes in a regulated free enterprise individualistic society which is human destiny, so long as history is prevented from intervening in the form of biotechnology which changes human nature. Nevertheless the restrictions that the two men want to impose on biotechnology and genetic research do not seem to differ much. Their arguments stand on completely different platforms, but their legislative acts would be similar.

13 James Mill and Macaulay battled it out between March 1829 and January 1830 in the Edinburgh Review (Macaulay) and the Westminster Review (Mill). The debate is collected in Liveley and Rees (1978); the quotation is from p. 101. 
Insofar as the distinction can be maintained, both are cautiously willing to permit therapeutic biotechnology, which Habermas characterizes as a form of medicine, as treating and helping the ill. Disability advocates want far more regulation than either of our two grand thinkers does. They fear that "therapeutic" intervention before birth would eliminate future people with disabilities. People with disabilities are worthy, now, and we have no right to preclude the future existence of similar people. Future possible non-existents thus have their advocates. Perhaps this mollifies some of Habermas' worry about asymmetric communication and determination. Future possible citizens do have their advocates right now.

For Fukuyama as free market regulator, the answer to the conundrum of disability may be easier. If we restrict therapy to illnesses, and after free debate accept that disabilities are not illnesses, then genetic elimination of disabilities counts as enhancement. Hence it is subject to strict regulation or outright prohibition. On the other hand, if after free debate we reach the opposite conclusion, that disabilities are, if not exactly illnesses, at least the sort of thing for which cures are possible, then in the free market there can be no prohibition on individuals preventing the occurrence in their own families.

Both Habermas and Fukuyama strongly discourage enhancement biotechnology. Part of their fear was foreshadowed by Huxley, whom Fukuyama expressly invokes. It is the fear of creating a new species of posthumans. In Brave New World, our species will have several subspecies, some of which are like worker ants, and some of which are blissful regulators. All members of each of the subspecies are happy with their status quo. Fukuyama does not forget Huxley's drug soma that keeps posthumans contented and unreflective. Much present psychopharmacology does seem to be aiming at developing just such a panaceatic medication.

Call the different subspecies of posthumans after Huxley's Alphas, Betas, Gammas, and Deltas. Due cause for alarm! Members of even the Alpha subspecies would have no need for human values, for Lewis' Tao. They would have none of the features that make our fellow humans worthy. That is indeed a dystopia. Of all the Jeremiahs, Huxley is still the most cogent. There is now a vogue among humanists of saying that we are entering a posthuman age. It is what they see as coming after postmodernism. It is supposed to be very enlightened. Very progressive. Very with it. Indeed I am myself frequently invited to well-funded conferences discussing the future of posthumanism. I always decline, saying that I hope posthumanism has no future. Yes, after being unkind about Fukuyama, I certainly share some of his attitudes. But my attitudes are more those of Lewis, who already in 1942 had coined the expression, "post-humanity". "Man's conquest of himself," he wrote, "means simply the rule of the Conditioners over the conditioned human material, the world of post-humanity which, some knowingly and some unknowingly, nearly all men in all nations are at present labouring to produce." (Lewis 2001 [1944], 71)

\section{3, 2009}

I conclude with an up to-the-minute dystopia, begun by Margaret Atwood with Oryx and Crake (2003), and continued in The Year of the Flood (2009). By the OED criterion, that a dystopia is a worst of all possible worlds, this is not strictly a dystopia, for Atwood opines that "It's bad news for some, but good news for others." After all, "the birds are doing better." "It could be much worse," she said in an interview, "it could be a nuclear book in which everything is grey and burnt" (Barber 2009). Indeed, the entire effect is like Jeremiah himself, plus biotech: "I beheld the mountains, and lo, they trembled, and 
all the hills moved lightly. I beheld, and lo, there was no man, and all the birds of the heavens were fled. I beheld, and lo, the fruitful place was a wilderness, and all the cities thereof were broken down ..." (Jer. 4: 24-26). Atwood allowed the birds to chirp, but Jeremiah said that even they would disappear.

By the time of the second book only two humans are known to be alive: everyone else appears to have died of an Ebola-type virus that turns your innards into mush. The lethal epidemic was a (dry) flood. (Perhaps as homage to Huxley, whose dates were AF - after Ford/Freud - the dates in the 2009 book are After Flood.)

The Crake of the first book's title is a Conditioner who has let ferocious glowing green rabbits into the world, putting an end to the familiar ones. He has spliced skunks and raccoons, but above all he has done extraordinary things to the human genome, producing a placid set of posthuman beings who don't think much and who have sex for procreative purposes only, when the females are in heat. Passion, imagination, and love are replaced by tranquility adapted to the scary new world in which disease has wiped out almost all the humans left after ecological cataclysms (all of the sort foretold by doomsayers today, but graphically enriched by a powerful writer).

So here we have a story about C. S. Lewis's worst fears. The Conditioners have abolished Man, and replaced him by a species of posthumans, Crake's children. Also the human race has been extinguished by ecodisaster, except for rare survivors, such as Jimmy who has become the solitary (abominable) Snowman to whom the 2003 book is anchored. In the 2009 book we get a better idea of what motivated Crake, the Conditioner. He suffered so from failed love for Oryx that he was driven to create a race of passionless, uncurious, posthumans. He is verily a Conditioner who has lost the Tao. But the book is not pure Lewis, because climate change has become climate disaster, good for getting rid of humans, but not because of biotechnology.

There is one great, and rather frightening, similarity between the fantasies of Huxley and Atwood. The Conditioners achieved what they set out to achieve. Their results were not a mistake: they were intended. In Brave New World the Conditioners engineered castes all members of which were happy in their station, or could be made so with a whiff of psychopharmacology in the form of soma. That was what was planned. Likewise for Crake's children who could well have adopted the motto of Huxley's state, "Community, Identity, Stability," except they are too placid, too stupid, to understand it. That was just what Crake intended. I do not know what Lewis thought about Brave New World, though I am sure a Lewis scholar can tell us. We can venture that Lewis would have diagnosed Crake as suffering from having fallen away from the Tao with which he really was imbued as an avid young researcher. It is striking that Lewis's name, "the Conditioners", so well fits Crake and the technicians whom Habermas and Fukuyama fear may get out of hand (out of mind).

\section{Transhumanism}

Now for a fraternal irony: Aldous Huxley published the greatest of dystopias in 1932. His brother was Julian, distinguished biologist and statesman of science. Late in life Julian Huxley took the opposite tack. In 1957, when he was seventy, he coined the word 'transhumanism' in a gush of optimistic fantasy:

"The human species can, if it wishes, transcend itself - not just sporadically, an individual here in one way, an individual there in another way, but in its entirety, as humanity. We need a name for this new belief. Perhaps transhumanism will serve: man remain- 
ing man, but transcending himself, by realizing new possibilities of and for his human nature.

I believe in transhumanism: Once there are enough people who can truly say that, the human species will be on the threshold of a new kind of existence, as different from ours as ours is from that of Pekin man. It will at last be consciously fulfilling its real destiny." (Huxley 1957, 13, 17)

Another Jules Verne type fantasy, which has been around for a very long time, is mimicking the brain of an actual human being on a computer. Nick Bostrom, president of the World Transhumanist Association, describes a "hypothetical technology" that he calls "uploading", namely:

"the transfer of a human mind to a computer. This would involve the following steps: First, create a sufficiently detailed scan of a particular human brain, perhaps by deconstructing it with nanobots or by feeding thin slices of brain tissues into powerful microscopes for automatic image analysis. Second, from this scan, reconstruct the neuronal network that the brain implemented, and combine this with computational models of the different types of neurons. Third, emulate the whole computational structure on a powerful supercomputer. If successful, the procedure would result in the original mind, with memory and personality intact, being transferred to the computer where it would then exist as software; and it could either inhabit a robot body or live in a virtual reality." (Bostrom 2005)

The author goes on to say that his fellow transhumanists "take different views" on what this actual or virtual being would be. I include this snippet of futurology as a piece of neo-Cartesian fantasy. ${ }^{14}$ This body part, the brain, is totally alienated from the now dead human owner. It is chopped up into slices, and mimicked, and lo, a new mind enters a robot body. Bostrom's utopia is my dystopia.

In the autumn of 2004 the journal Foreign Policy ran a symposium on "the world's most dangerous ideas." (Fukuyama et al. 2004) It posed a question to eight leading intellectuals. Which idea now in circulation would be most harmful to the world as we know it, if it were to be carried through? Fukuyama was one of the eight. The worst idea now going the rounds, he said, is Transhumanism.

\section{Precaution}

In recent years a 'Precautionary Principle' has become prominent, first in Germany, and then in much of Europe. It is directed at changes that may have permanent harmful effects, but where the situation is not well enough understood to apply cost-benefit analysis. Radical change is forbidden when the evidence, that benefits will outweigh the possible permanent harms, is inadequate. Thus the principle shifts the burden of proof: Before you do anything, show that no permanent harm could result. In 2000 the European Commission tried to clarify such statements, and, more importantly, explain how and when they may be used. A significant amount of European and international legislation and case law is developing around the precautionary principle. It may have taken hold in Australia and Brazil. It has some standing in Canadian jurisprudence, but absolutely none in the United States.

14 On the implicit resurgence of Cartesianism in our times, see Hacking 2007. 
We surely need caution, for it is a good hunch that sooner or later, something will go badly wrong. In 1995 I was present at a popular lecture about Ebola, given by an eminent epidemiologist: it scared the living daylights out of me and, I think, everyone else in the room. Atwood may have had a similar experience. She takes future diseases far more seriously than most of us: she wrote the foreword for The Flu Pandemic and You: A Canadian Guide. (Lam and Lee 2006) Being a novelist, she has to add verisimilitude by tying her models closely to a worst possible scenario relative to what we at present know. (In fact the more you know of her home town, Toronto, the more you may recognize; my family doctor works today in a building which, still standing, provides refuge for a colony shortly before the year of the Flood.) But the worst is something outside of our imagination, something unthinkable.

This may seem incoherent, but the example of the Nile illustrates the point. From the amazing natural variety of grasses, Mesopotamian Neolithic farmers selected and propagated a type of wheat (Emmer wheat, Triticum dicoccon). Egyptians tamed the estuary of the Nile, and established intensive cultivation of this grain. That enabled a large population to dwell near slow-moving or stagnant water. It led to one of the great leaps forward for civilization. But it also facilitated a variety of mosquito carrying a variety of malaria. Natural selection followed in train with a strain of Egyptians who were to some extent immune: this was evolution of the sickle cell gene.

The mutation spread very rapidly, so it must have had high protective value, with those unprotected dying off quickly. Probably most of the new farmers never lived to harvest their own crops, leaving only a few immune people to repopulate the delta. ${ }^{15}$ These events were completely outside the conceptual scheme of the Egyptians. No soothsayer could have conceived that a new system of agriculture would have produced either the "cradle of civilization," or the parasite - let alone the subsequent immunity. An Ebola-like virus wiping out our species is all too conceivable (especially after that 1995 lecture I mentioned), and so, for me, it has not quite reached the edge of terror.

We literally cannot worry about things we cannot conceive, and we cannot guard against them just because they are unthinkable. Precautionary principles go one step beyond probability: that is, they urge caution in precisely those situations where calculations of expectation have no foundation. But they do not go beyond what can be envisioned. We should also fear that which we cannot think.

Doubtless there were prophets in the Nile, decrying change, and others declaring that it would work out right in the end, but that is not enough for the exercise of any legitimate principle of precaution. It does show that indiscriminate worry about the unknown is not always misplaced. On the other hand, a principle of precaution is not going to save us from the inconceivable that may lie in wait for us.

\section{What then shall we do?}

There is something of a "popular front" - a de facto coalition of very different interests that happen to unite on a particular and pressing issue. Our first Jeremiah, C. S. Lew-

15 Similar but not identical mutations of first mosquito and parasite and then humans in response, arose independently when other civilizations expanded rapidly, as in West Africa during the ninth century, when large tracts of forest were felled for the cultivation of yams. 
is, wrote from a background of what he believed to be universal human values. He was indeed a converted Christian, but his Tao is witnessed from the corners of the globe; his selection of sayings may have Christian inspiration, but the sayings themselves represent, he would say, all cultures. Our second Jeremiah, Habermas, is self-consciously situated as a contemporary European in a pluralistic society which, unlike an earlier Europe, cannot take any current system of values for granted, certainly not a Christian one. There are values, yes, autonomy and dignity, but none that are embedded in anything more specific than a commitment to respectful communication. Our third Jeremiah, Fukuyama, is a triumphalist who believes that the Enlightenment virtues of "Human Nature," absorbed into American exceptionalism, comprise the inevitable value system of the coming world order. All three are frightened by the very way in which biotechnology may become an end in itself, an absolutely fascinating way of altering the world and ourselves, so fascinating that we risk forgetting the values that legitimate the exercise of our powers over nature. Their demand for regulation and control of biotechnological enterprise, or sometimes withdrawal from it, is robust, in a technical sense of that word. That is, they reach remarkably similar conclusions starting from radically different commitments. As if all roads lead in the same direction.

Early on I suggested that dystopias and jeremiads need each other. Taken one by one, arguments of the jeremiads are not, in my opinion, strong. The visions of the dystopias are not probable, but they cast in graphic exaggeration exactly what the Jeremiahs are afraid of. Hence jeremiads and dystopias reinforce each other, in part because they appeal to two different facets of the ways in which we act, decide, hope, or fear. Thinkers called rational are supposed to be moved only by reason, but notoriously the rational man is a thin man imagined by utilitarians. Actors called emotional are supposed to be chiefly moved by their gut feelings, and thereby to be unsteady as the gut changes. Both facets are essential to the values that all our authors share, underneath their ideological differences. I suggest that anyone who takes cognizance of both the jeremiads and the dystopias will come to support something like the modest bio-conservative positions that are shared, for different reasons, by Fukuyama and Habermas. This not because there are compelling reasons, and not purely out of naïve fear, but out of the combination of the two, a combination that strongly underlies the 120 sayings that constitute C. S. Lewis's Tao.

\section{Bibliography}

Atwood, M. (2003) Oryx and Crake. Toronto: McClennan and Stewart.

Atwood, M. (2009) The Year of the Flood. Toronto: McClennan and Stewart.

Barber, J. (2009) Atwood: 'Have I Ever Eaten Maggots? Perhaps ...' - an interview with

Margaret Atwood. In: The Globe and Mail, 12 September 2009.

Bostrom, N. (2005) A History of Transhumanist Thought. In: Journal of Evolution and Technology 14(1): 1-25.

Dyson, F. (2007) Our Biotech Future. In: New York Review of Books 54(12).

Fukuyama, F. (2002) Our Posthuman Future: Consequences of the Biotechnology Revolution. New York: Farrar, Straus and Giroux.

Fukuyama, F. et al. (2004) The World's Most Dangerous Ideas. In: Foreign Policy 144 (September/October): 32-65.

Galton, F. (1883) Inquiries into Human Faculty and Its Development. London: Macmillan. 
Habermas, J. (2001) Die Zukunft der menschlichen Natur: Auf dem Weg zu einer liberalen Eugenik? Frankfurt M.: Suhrkamp.

Habermas, J. (2001) The Future of Human Nature. Transl. H. Beister, M. Pensky and W. Rehg. Malden, MA: Polity Press.

Hacking, I. (2007) Our Neo-Cartesian Bodies in Parts. In: Critical Inquiry 34(1): 78-105.

Hacking, I. (2008) Deflections. In: Cavell, S./Diamond, C./McDowell, J./Hacking, I./Wolfe, C. Philosophy and Animal Life. New York: Columbia University Press.

Haran, J./Kitzinger, J./McNeil, M./O'Riordan, K. (2008) Human Cloning in the Media: From Science Fiction to Science Practice. Oxford and New York: Routledge.

Huxley, J. (1957) Transhumanism. In: New Bottles for New Wine. London: Chatto \& Windus, 13-17.

Lam, V./Lee, C. (2006) The Flu Pandemic and You: A Canadian Guide. Toronto: Doubleday Canada.

Lewis, C. S. (2001) The Abolition of Man: Or, Reflections on Education with special reference to the Teaching of English in the Upper Forms of Schools. San Francisco: Harper. [Original edition: Oxford University Press, 1944.]

Lewis, C. S. (1938) Out of the Silent Planet. London: Bodley Head.

Lewis, C.S. (1943) Perelandra. London: Bodley Head.

Lewis, C. S. (1945) That Hideous Strength. London: Bodley Head.

Lively, J./Rees, J. (eds.) (1978) Utilitarian Logic and Politics: James Mill's 'Essay on Government', Macaulay's Critique and the Ensuing Debate. Oxford: Oxford University Press.

Lock, M. (2002) Twice Dead: Organ Transplants and the Reinvention of Death. Berkeley: University of California Press.

Merchant, C. (1980) The Death of Nature: Women, Ecology, and the Scientific Revolution. San Francisco: Harper \& Row.

Merchant, C. (2006) The Scientific Revolution and the Death of Nature. In: ISIS 97(3).

More, T. (2002) Utopia. Adams, E./Logan, J. (eds.). Cambridge: Cambridge University Press. [Original Latin, 1516]

Rose, S. (2005) The 21st Century Brain: Explaining, Mending and Manipulating the Mind. London: Jonathan Cape.

Shachar, A. (2009) The Birthright Lottery: Citizenship and Global Inequality. Cambridge, MA: Harvard University Press.

Stacie, J. (2009) The Cinematic Life of the Gene. Durham, N.C.: Duke University Press.

Ian Hacking is Professeur honoraire at the Collège de France and University Professor Emeritus at the University of Toronto. He is the author of books on topics as diverse as probability, experimental science, mental illness, and "social construction". His 2002 Historical Ontology (Historische Ontologie, Chronos Verlag 2006) is a collection of papers that illustrates some of his approaches to philosophical analysis.

E-Mail: ian.hacking@college-de-france.fr 